Published in Journal of Hydrology 310 (2005) 280 - 293

\title{
Groundwater use by vegetation in a tropical savanna riparian zone
}

\author{
(Daly River, Australia)
}

Sébastien Lamontagne ${ }^{\mathrm{a},{ }^{*}}$, Peter G. Cook ${ }^{\mathrm{a}}$, Anthony O’Grady ${ }^{\mathrm{b}, \mathrm{t}}$ and Derek Eamus ${ }^{\mathrm{c}}$

${ }^{\mathrm{a}}$ CSIRO Land and Water, Urrbrae SA 5064

${ }^{\mathrm{b}}$ Key Centre for Tropical Wildlife Management, Northern Territory University Darwin NT 0909

${ }^{\mathrm{c}}$ Institute for Water and Environmental Resource Management, University of Technology, Sydney, PO Box 123, Broadway NSW 2007

*Corresponding author: Fax: +61-8-8303-8750

${ }^{\#}$ Current Address: CRC/CSIRO Forestry, GPO Box 251-12, Hobart 7001 TAS

E-mail addresses: sebastien.lamontagne@ csiro.au (S. Lamontagne), peter.g.cook@csiro.au (P.G. Cook), tony.o'grady@ffp.csiro.au (T. O’Grady) derek.eamus@uts.edu.au (D. Eamus) 


\section{Abstract}

Soil matric potentials and the deuterium $\left(\delta^{2} \mathrm{H}\right)$ composition at natural abundance levels of xylem water, soil water and groundwater were used to evaluate whether trees use groundwater during the dry season in the riparian zone of the Daly River (Northern Territory, Australia). Groundwater was a significant source of water for plant transpiration, probably accounting for more than $50 \%$ of the water transpired during the dry season. Several water use strategies were inferred within the riparian plant community. Melaleuca argentea W. Fitzg and Barringtonia acutangula (L.) Gaertn.) appeared to be obligate phreatophytes as they used groundwater almost exclusively and were associated with riverbanks and lower terraces with shallow $(<5$ m) water tables. Several species appeared to be facultative phreatophytes (including Cathorium umbellatum (Vahl.) Kosterm. and Acacia auriculiformis A. Cunn. ex Benth.) and tended to rely more heavily on soil water with increased elevation in the riparian zone. The levee-bound Corymbia bella K.D. Hill \& L.A.S. Johnson mostly used soil water and is either a facultative phreatophyte or a non-phreatophyte. The temporal variability in groundwater utilisation by the trees is unclear because the study focused on the end of the dry season only. A decline in the regional water table as a result of groundwater pumping may affect the health of riparian zone vegetation in the Daly River because groundwater use is significant during the dry season.

Keywords: groundwater/transpiration/riparian zone/tropical savanna/phreatophyte 


\section{Introduction}

Throughout northern Australia, agricultural and industrial development is expanding rapidly. Major large-scale land developments are planned for the Daly River region, in the tropical savanna of the Northern Territory (Fig. 1). These largescale changes in land use are expected to have a significant impact on regional water balance and resources. Notably, the exploitation of groundwater resources will almost inevitably impact groundwater-dependent ecosystems (Sophocleous, 1997; Hatton and Evans, 1998). However, as landscape development is still in its early phases in northern Australia, there is an opportunity to design the exploitation of groundwater resources to minimise future impacts to the environment (Cook et al., 1998; Sophocleous, 2000). This requires groundwater dependent ecosystems to be identified and their environmental water requirements to be better understood and quantified (Clifton and Evans, 2001).

A number of potentially groundwater dependent ecosystems have been identified in the tropical savanna (Cook et al., 1998), including baseflow rivers and associated riparian communities. Riparian vegetation is an integral component of river systems and is vital for maintaining a number of key ecosystem services (Bunn, 1993; Patten, 1998). Currently, it is not possible to evaluate the impact of future land management scenarios on the riparian community of the Daly River because groundwater dependency has not been established. However, it is suspected that phreatophytes are present because they are common in climates with prolonged dry seasons (Canadell et al., 1996; Jackson et al., 1996) and in riparian zones in general (Mensforth et al., 1994; Thorburn et al., 1994; Horton et al., 2001). Both obligate phreatophytes (i.e. species that use groundwater almost exclusively at all times) and facultative phreatophytes (i.e. species that use groundwater in an opportunistic 
fashion) have been found in riparian zones (Stromberg et al., 1996; Horton et al., 2001).

Using the deuterium $\left(\delta^{2} \mathrm{H}\right)$ signature of xylem water, soil water and groundwater, we present the first assessment of groundwater dependency in a riparian plant community in the Australian tropical savanna. The abundance of the naturally occurring stable isotopes of water is a standard tool to determine the source of water used by plants (Dawson and Ehlringer 1991; Jackson et al. 1999; Adams and Grierson 2001). In this study, we first examined the spatial variability in $\delta^{2} \mathrm{H}$ in xylem water, soil water and groundwater along transects spanning the elevation gradient of the riparian zone. Secondly, groundwater use was further determined by comparing xylem $\delta^{2} \mathrm{H}$ to soil water $\delta^{2} \mathrm{H}$ profiles and soil matric potential profiles at different landscape positions (riverbanks, terraces and levees). Data collection focussed on the end of the dry season, when groundwater use should have been greatest.

\section{Study area}

The Daly River is one of the large rivers of tropical Australia, with a catchment area of approximately $52600 \mathrm{~km}^{2}$ (Fig. 1). The climate of the region is dominated by a distinct monsoonal wet season occurring from October until April (i.e. the austral summer) and a winter dry season (Faulkes, 1998). Mean annual rainfall for Katherine and the Douglas Daly Research farm (at the junction of the Douglas and Daly rivers; Fig. 1) is $1073 \mathrm{~mm}$ and $1157 \mathrm{~mm}$, respectively. The average annual potential evaporation at Katherine is $2044 \mathrm{~mm}$. Minimum and maximum daily air temperatures are fairly constant throughout the year, varying from 
$20.4^{\circ} \mathrm{C}$ to $43.1^{\circ} \mathrm{C}$ on average at Katherine. Forest fires are common during the dry season.

The source of water used by riparian trees was evaluated at two sites (Oolloo and Douglas/Daly) in the middle section of the river, where development pressure is greatest. The riparian zone at Oolloo had a width of 80 to $100 \mathrm{~m}$ from river baseflow level to the top of the levee, representing a $\sim 20 \mathrm{~m}$ difference in elevation. The Douglas/Daly site was located on a triangular land wedge at the junction of the Douglas and Daly rivers (Fig. 1). At the Douglas/Daly transects, the distance from river to river was $\sim 150 \mathrm{~m}$ and the maximum height above baseflow river level was $\sim 11 \mathrm{~m}$. The Oolloo site is located in a regional groundwater discharge area (Cook et al., in press). Groundwater levels in the riparian zone at the Douglas/Daly site are probably mostly controlled by changes in river level.

\subsection{Riparian vegetation}

Vegetation within the Daly River catchment is dominated by Eucalyptus woodlands and open forests. However, other communities occur including: closed forests, riparian vegetation, Melaleuca communities, floodplain communities, and mangroves. Near streams and rivers, the riparian zone varies in width from a single line of trees to dense closed forests spreading up to levee banks and contains many species typical of monsoon-closed forests such as Nauclea orientalis (L.) L. and Barringtonia acutangula (L.) Gaertn. (Faulkes, 1998). In general, the riparian vegetation exhibits a distinct zonation as a function of elevation. The riverbanks are steep and rise in a series of terraces from the river. Melaleuca argentea W. Fitzg. and Melaleuca leucadendra (L.) L. occur on the lower terraces and along the riverbanks. Behind this strip of Melaleuca, the terraces are often dominated by monsoon-closed 
forest communities, including Cathorium umbellatum (Vahl.) Kosterm., Leptospermum grandiflorum Lodd. and Strichnos lucida R. Br. Corymbia bella K.D. Hill \& L.A.S. Johnson and several Eucalyptus species are common along levee banks. A few species, including Acacia auriculiformis A. Cunn. ex. Benth. and Casuarina cunninghamiana Miq., can be found across the riparian zone.

\section{Methods}

Samples of river water, xylem water, soil water and groundwater were collected in September 2000 and August 2001 (i.e. late in the dry season) along transects at the Douglas/Daly and Oolloo sites. At the Douglas/Daly site, two transects were sampled in September 2000 (Douglas/Daly Transect 1 and Transect 2) and a third transect in August 2001 (Douglas/Daly Transect 3). At the Oolloo site, one transect (Oolloo Transect 1) was sampled in both September 2000 and August 2001 and an additional transect (Oolloo Transect 2) in August 2001 only. Each transect extended across the riparian zone from the riverbank to the levee. To test whether differences in $\delta^{2} \mathrm{H}$ values were due to landscape position or species attributes, Douglas/Daly Transect 3 and Oolloo Transect 2 were selected because they had one species found across the elevation gradient (A. auriculiformis and C. cunninghamiana for Douglas/Daly Transect 3 and Oolloo Transect 2, respectively). The location of trees and the cross-sectional profile of each transect were measured using a laser theodolite.

Xylem water ( 1 to 3 trees per species per transect) was sampled by collecting three twig samples of 10-25 mm diameter from the canopy using pruning shears. The trees sampled were mature, with DBH generally ranging from 10 to $50 \mathrm{~cm}$. The twigs 
were stripped of bark, cut into 50-mm lengths, placed in McCartney bottles (i.e. robust glass vials with air-sealed screwcaps), and covered with kerosene prior to sealing. River samples were collected from close to the bank at approximately $0.5 \mathrm{~m}$ depth at each sampling site. Groundwater samples were collected when water entered augered holes, directly from springs as they emerged from the ground along the terraces or banks of the river, and from one bore used as a drinking water supply at the Douglas Daly Research Farm ( 1 km from the Douglas/Daly site). Soil profiles were collected by hand-augering to depths of up to $7 \mathrm{~m}$, with samples taken at 0.1 , $0.2,0.5 \mathrm{~m}$, and then at $0.5 \mathrm{~m}$ intervals. Soil samples were placed in glass jars sealed with screw caps and electrical tape to minimise evaporation and stored in insulated containers for transport from the field to the laboratory. In each soil profile, the soil matric potential was measured at every meter using the filter paper method (Greacen et al., 1989). In addition, 2 to 3 soil samples per profile in 2000 and 4 to 5 samples per profile in 2001 were used to characterise the range in soil water $\delta^{2} \mathrm{H}$ values.

Water was extracted from plant and soil samples using azeotropic distillation (Revesz and Wood, 1990; Thorburn et al., 1993). Water samples were analysed for $\delta^{2} \mathrm{H}$ through stable isotope mass spectrometry by reducing $25 \mu \mathrm{l}$ of water to $\mathrm{H}_{2}$ over uranium at $800^{\circ} \mathrm{C}$. Samples were analysed using a dual inlet gas ratio mass spectrometer (Europa Scientific Ltd). Isotopic concentrations were expressed as delta ( $\delta)$ values per mil (\%o) relative to the standard SMOW (Standard Mean Ocean Water). Delta values were calculated using the formula:

$$
\delta(\%)=\left(\frac{R_{i}}{R_{s}-1}\right) \cdot 1000
$$


where $R_{i}$ is the ratio of the heavy to the light isotope in a sample and $R_{s}$ the same ratio in a standard. The error on plant and soil water $\delta^{2} \mathrm{H}$ estimates obtained with the azeotropic distillation is usually less than $\pm 5 \%$ (Walker et al., 2001).

\section{Results}

\subsection{Patterns in deuterium across the riparian zone}

At Oolloo (Fig. 2), shallow groundwater in the riparian zone had a narrow range in $\delta^{2} \mathrm{H}$ values (mean $\pm \mathrm{SD}=-45.3 \% \pm \pm 1.6 ; n=5$ ) similar to the one of the Daly River during baseflow $(-44.8 \% \pm 1.1 ; n=8)$ and of regional groundwater (mean of twelve springs sampled along the banks of the Daly River between Oolloo and Douglas/Daly $=-43.9 \%$ $\pm 5.6 ;$ P. Cook, unpublished data $)$. In contrast to groundwater and surface water, soil water $\delta^{2} \mathrm{H}$ values (excluding water from the capillary fringe) were more negative and more variable ( -91 to $-56 \%$ in 2000 and 87 to $-40 \%$ in 2001). At Oolloo Transect 1 in 2000, both riverbank M. argentea ( -48 to $-43 \%$ ) and terrace B. acutangula ( -46 to $-40 \%$ ) had $\delta^{2} \mathrm{H}$ values similar to river/groundwater (Fig. $2 a$ ). In contrast, levee $C$. bella had more negative $\delta^{2} \mathrm{H}$ ( -71 to $-59 \%$ ). In 2001, a similar pattern occurred for trees along the same transect (Fig. $2 b$ ) and for C. cunninghamiana along Transect 2 (Fig. 2c).

At the Douglas/Daly site, the $\delta^{2} \mathrm{H}$ signature of the Douglas River $(-40.3 \%$. \pm $0.6 ; n=2)$ was less negative relative to the one of the Daly River $\left(-44.2 \%_{0} \pm 1.4 ; n=\right.$ 2). No riparian groundwater samples was available at the Douglas/Daly transects. However, a drinking water bore sampled at the Douglas Daly Research farm $(\sim 1 \mathrm{~km}$ from the transects) had a $\delta^{2} \mathrm{H}$ value of $-42.2 \%$ ( $\mathrm{P}$. Cook, unpublished data) and the 
$\delta^{2} \mathrm{H}$ values of soil water from the capillary fringe (which should be similar to groundwater) ranged between -45 to $-42 \%$ (see Soil water profiles below). In 2000 , soil water $\delta^{2} \mathrm{H}$ values ranged from -67 to $-50 \%$ at the terrace profiles and from -104 to $-31 \%$ at the levee profiles (Figs. $3 a-b$ ). The pattern in tree $\delta^{2} \mathrm{H}$ values with elevation in the riparian zone was not as pronounced relative to the Oolloo site. At transects 1 and 2 (Figs $3 a-b$ ), riverbank M. argentea, L. grandiflorum and $B$. acutangula had $\delta^{2} \mathrm{H}$ values similar to river/groundwater (-42 to $-40 \%$ ). On terraces and levees, $C$. umbellatum had more negative $\delta^{2} \mathrm{H}$ values ( -56 to $-43 \%$ ) while $C$. bella were intermediate ( -49 to $-43 \%$ ). At Transect 3 in August 2001 (Fig. 3c), A. auriculiformis also had more negative $\delta^{2} \mathrm{H}$ values when away from the river.

\subsection{Soil water profiles}

With some assumptions on the lower water potentials at which riparian trees from the Daly River can extract soil water (see Discussion), the soil matric potential and the soil water deuterium profiles can be combined to further constrain from where trees were accessing water. For brevity, an emphasis is given here on the more detailed 2001 soil profiles. On the levee at Oolloo Transect 1, matric potentials were less negative than -1.5 MPa throughout the soil profile with the exception of the top 0.5 metres (Fig. 4a). The range in levee soil water $\delta^{2} \mathrm{H}$ values was large, ranging from $-40 \%$ at $1-\mathrm{m}$ to $-87 \%$ at $3.5-\mathrm{m}$, and back to $-45 \%$ at $5.5-\mathrm{m}$ (Fig. $4 b$ ). The $\delta^{2} \mathrm{H}$ value of a nearby Poinciana sp. was $-55 \%$, similar to soil water $\delta^{2} \mathrm{H}$ values at depths ranging between $1-2 \mathrm{~m}$ and 5-5.5 $\mathrm{m}$. On the terrace, the capillary fringe (matric potential $\sim 0 \mathrm{MPa}$ ) extended up to $1.5 \mathrm{~m}$ above the water table (Fig. $4 c$ ). Above the capillary fringe, matric potentials ranged between -2.2 and $-1 \mathrm{MPa}$. The $\delta^{2} \mathrm{H}$ value of one Pongamia pinnata near the soil profile $(-55 \%)$ was within the range found in soil 
water $(-60$ to $-51 \%$; Fig. $4 d$ ). At the riverbank soil profile, the water table was $2.5 \mathrm{~m}$ below the soil surface and the capillary fringe extended to about $1 \mathrm{~m}$ of the soil surface (Fig. $4 e$ ). Groundwater $(-46 \%)$, soil water in the capillary fringe ( -48 to $46 \%$ ) and xylem water for three M. argentea ( -48 to $-47 \%$ ) had similar $\delta^{2} \mathrm{H}$ values (Fig. 4f).

The soil profiles at the Douglas/Daly site had more negative matric potentials than at the Oolloo site. At the Douglas/Daly Transect 3 levee profile (Fig. 5a), matric potentials were more negative than $-3.5 \mathrm{MPa}$ from the surface to 4-m. Deuterium in the soil profile increased from $-70 \%$ at $2-\mathrm{m}$ to $-40 \%$ at $5-\mathrm{m}$, with a nearby $A$.

auriculiformis having a $\delta^{2} \mathrm{H}$ value of $-63 \%$ (Fig. $5 b$ ). On the terrace, matric potentials were more negative than $-1 \mathrm{MPa}$ from the surface to $4.5-\mathrm{m}$ depth but less negative than $-1 \mathrm{MPa}$ in the vicinity of the water table (Fig. $5 c$ ). Deuterium in the terrace soil profile also increased with depth, from $-61 \%$ at $2-\mathrm{m}$ to $-53 \%$ at $5-\mathrm{m}$ (Fig $5 d$ ), with a nearby $A$. auriculiformis having a deuterium value of $-49 \%$. Matric potentials were very negative (less than $-2.5 \mathrm{MPa}$ ) throughout the unsaturated zone at the riverbank profile (Fig. 5e). Deuterium in the riverbank soil profile declined with depth, from $-55 \%$ at $2-\mathrm{m}$ to $-42 \%$ at $3-\mathrm{m}$. Deuterium in one riverbank $A$. auriculiformis ( $-38 \%$ ) was close to the signature expected for the Douglas River (40\%; Fig. 5f).

\section{Discussion}

\subsection{Establishing groundwater dependency in the Daly riparian zone}

Unlike some other forest types in the Northern Territory (Hatton et al., 1998), a distinct deuterium signature between soil water and groundwater allowed to assess 
groundwater use in the Daly River riparian zone. The overlap in $\delta^{2} \mathrm{H}$ signatures between groundwater and the Daly River is consistent with regional groundwater being the main source of baseflow for the river during the dry season (Cook et al., in press). Based on $\delta^{2} \mathrm{H}$ values, groundwater was an important source of water for transpiration in the Daly riparian zone. Trees on riverbanks used mostly groundwater and those on terraces either used soil water, groundwater, or a mixture of both. Trees on levees were the most reliant on soil water but some may have used groundwater as well.

Groundwater use can be further inferred by making some assumptions about the lowest soil water potential at which riparian trees can utilise soil water. Based on data from other species in Australian tropical savannas and other Australian semi-arid climates, Daly River riparian trees probably prefer to use soil water at tensions less negative than $-1 \mathrm{MPa}$ but may be able to access soil water at tensions as low as -3.5 MPa (Duff et al., 1997; Prior et al., 1997; Walker et al., 2001; Thomas and Eamus, 2002). The combination of the matric potential and deuterium profiles indicate that, near the end of the dry season, trees were frequently sourcing water deep in the soil profile or from the capillary fringe (i.e. using groundwater). For example, on the terrace at Oolloo in 2001 (Fig. 4c-d), the deuterium signature in P. pinnata overlaped the soil signature at 3-m, which was also the region of the soil profile when matric potentials became less negative than $-1 \mathrm{MPa}$. Likewise, the deuterium signature of $A$. auriculiformis on the levee at Douglas/Daly (Fig. 5a-b) overlaped the one in the soil profile near 4-m, also the depth where soil tensions became less negative than -3.5 MPa. On the same transect at the riverbank (Fig. 5e-f), the matric potential profiles indicate that A. auriculiformis was extracting some of its water from the capillary fringe. More definitive interpretation of the soil matric potential profiles while 
require that the minimum soil tensions at which the different riparian tree species can extract water be defined (for example, through repeated measurements of the minimum pre-dawn leaf water potentials during drought periods). However, the patterns in soil water potentials are consistent with significant groundwater use on riverbanks and terraces.

At the riparian stand scale, the proportion of transpiration originating from groundwater is significant in the Daly River. While riverbanks and lower terraces cover less than half of the riparian zone, they also have a greater stand basal area than on upper terraces and levees (O’Grady et al. 2003). By assuming that transpiration was $100 \%$ derived from groundwater within either 20 or $40 \mathrm{~m}$ from the river, O'Grady et al. (2003) estimated that 59 to $78 \%$ of riparian stand transpiration was derived from groundwater during the dry season.

\subsection{Water sourcing strategies in the Daly riparian zone}

While the number of individuals sampled per tree species was limited $(<8)$, it is possible to speculate on the water sourcing strategies for some of the more common species found in the Daly River riparian zone. Possible obligate phreatophytes include $M$. argentea and B. acutangula as these species always had xylem deuterium signatures similar to groundwater and were restricted to areas with shallow water tables (i.e., <5 m). Several species (including A. auriculiformis and C. umbellatum) appeared to be facultative phreatophytes and their pattern of groundwater use may be a function of their position in the landscape (with a larger proportion of soil water use at higher elevations). The pattern in water use in levee-bound $C$. bella is not clear at the present. This species may rely principally on soil water but it cannot be excluded that it may also be a facultative phreatophyte. Too little information is currently 
available to determine the water use strategy for the other tree species present in the Daly riparian zone. The seasonal pattern in groundwater use also cannot be determined because our sampling focused on the end of the dry season. However, the patterns in soil water potentials observed at the Daly River are consistent with the tendency for facultative phreatophytes to gradually revert to deeper soil water and groundwater use later during the dry season.

Plant water use in the Daly River riparian zone is consistent with strategies observed elsewhere in similar environments. A number of strategies were used in a phreatophytic Banksia community on a sand dune system overlying a shallow aquifer in Western Australia (Zencich et al., 2002). At this site, the shallow-rooted perennial shrub Hibbertia hypericoides used mostly soil water, except when the water table was near the surface $(<3 \mathrm{~m})$. Banksia attenuata and B. ilicifolia were shown to be facultative phreatophytes, using primarily soil water in surface layers when available (winter/spring) but increasing their reliance on groundwater following prolonged drought periods. However, B. attenuata appeared to rely almost exclusively on soil water when the water table was deep (i.e., >30 m). In a Brazilian savanna, Jackson et al. (1999) found that four evergreen species and one deciduous species acquired water primarily from shallow (i.e., $<2 \mathrm{~m}$ ) soil layers while three deciduous and one evergreen species used deeper water resources. Phreatophytes from the semi-arid River Murray floodplain have been shown to have an opportunistic pattern in water use (Mensforth et al., 1994; Thorburn et al., 1994; Jolly and Walker, 1996). For example, Eucalyptus largiflorens in a recently flooded area of the River Murray floodplain were using flood-derived soil water while trees in non-flooded areas were using groundwater (Jolly and Walker, 1996). Similarly, Eucalyptus camaldulensis used a mixture of stream water, soil water and groundwater that varied as a function 
of the distance from a surface water body, soil water potential, and groundwater salinity (Mensforth et al., 1994; Thorburn et al., 1994).

The main conclusion from the comparison of deuterium in trees, soil water and groundwater is that groundwater is an important source of water for transpiration in the Daly riparian zone. However, a more detailed analysis of the seaonal water regime for different species will be required to determine which species are obligate, facultative or non-phreatophytes. It would be desirable to contrast water sourcing between wet and dry years (Horton et al., 2001). As observed elsewhere, some trees may only revert to groundwater use during drought periods, when all other sources are unavailable (Mensforth et al., 1994; Dawson and Pate, 1996; Zencich et al., 2002). While groundwater may constitute a small proportion of water use in facultative species, it is probably still important for their long-term survival as in this region annual potential evapotranspiration is larger than rainfall.

\subsection{Environmental water requirements for riparian phreatophytes}

Assessing the environmental water requirements of riparian phreatophytes is more complex than establishing groundwater dependence (Clifton and Evans, 2001). The environmental water requirements of phreatophytes can be a complex function of several attributes of groundwater systems (including attributes related to the quantity and quality of groundwater). For example, each species may have a physiological limit to the depth and rate of groundwater extraction (Clifton and Evans, 2001; Zencich et al., 2002), or a maximum salinity level above which groundwater cannot be used (Mensforth et al., 1994). In addition, which attribute will be significant can vary for different phases of the life cycle. For example, the rate of water table decline can limit seedling recruitment (Horton and Clark, 2000; Amlin and Rood, 2002) but 
may not compromise the health of trees with established root systems.

The stable isotopes of water are useful to establish groundwater dependence in phreatophytes but must be combined with other approaches to define environmental water requirements. The patterns in species distribution relative to the depth of the water table (Stromberg et al., 1996) and the contrast in water use between wet and dry years (Horton et al., 2001; Zencich et al., 2002) are often used as starting points to estimate the environmental water requirements of phreatophytes. For example, for the Daly River, trees relying almost exclusively on river or groundwater were usually located over water tables shallower than $5 \mathrm{~m}$ (Fig. 6). This relationship can be used to predict potential impacts on phreatophytes of a lowering of the water table. The health of the obligate phreatophytes could be compromised if the water table declines below 5 metres because they may loose access to groundwater. The health of facultative phreatophytes would be less likely to be compromised because they may revert to soil water use if groundwater becomes unavailable. However, facultative phreatophytes may undergo more frequent periods of water stress (and reduced

productivity) when water tables are lowered. A long-term lowering of the water table may reduce biodiversity in the riparian zone by promoting a gradual change towards species less dependent on groundwater.

\section{Acknowledgements}

We would like to thank the staff at the Douglas/Daly research farm for use of their facilities on the Douglas/Daly research farm (Department of Primary Industries and Fisheries). Staff from the Department of Infrastructure, Planning and Environment also provided valuable assistance especially Roger Farrow, Peter Jolly, David Georges and Errol Kerle. Kate Holland and Ray Froend provided useful comments 
on an earlier draft of the manuscript. This project was supported by CSIRO Land and Water, and the Environment Australia Healthy Rivers Program. 


\section{References}

Adams, M.A., Grierson, P.F., 2001. Stable isotopes at natural abundance in terrestrial plant ecology and ecophysiology. Plant Biology 3, 299-310.

Amlin, N.M., Rood, S.B., 2002. Comparative tolerance of riparian willows and cottonwoods to water table decline. Wetlands 22, 338-346.

Bunn, S.E., 1993. Riparian-stream linkages: Research needs for the protection of instream values. Australian Biologist 6, 46-51.

Canadell, J., Jackson, R.B., Ehleringer, J.R., Mooney, H.A., Sala, O.E., Schulze, E.D., 1996. Maximum rooting depth of vegetation at the global scale. Oecologia $108,583-595$.

Clifton, C., Evans, R., 2001. Environmental water requirements to maintain groundwater dependent ecosystems. Environmental flows initiative technical report number 2, Department of Environment and Heritage, Canberra. http://www.deh.gov.au/water/rivers/nhrp/groundwater/pubs/groundwater.pdf.

Cook, P.G., Favreau, G., Dighton, J.C., Tickell, S., (in press). Determining natural groundwater influx to a tropical river using radon, chlorofluorocarbons and ionic environmental tracers. Journal of Hydrology.

Cook, P.G., Hatton, T.J., Pidsley, D., Herczeg, A.L., Held, A., O’Grady, A.P., Eamus D., 1998. Water Balance of a tropical woodland Ecosystem, northern Australia: a combination of micro-meteorological, soil physical and groundwater chemical approaches Journal of Hydrology 210, 161-177

Dawson, T.E., Ehleringer, J.R., 1991. Streamside trees that do not use stream water. Nature 350, 335-37. 
Dawson, T.E., Pate, J.S., 1996. Seasonal water uptake and movement in root systems of Australian phreatophytic plants of dimorphic root morphology: a stable isotope investigation. Oecologia 107, 13-20.

Duff, G.A., Myers, B.A., Williams, R.J., Eamus, D., O’Grady, A.P., Fordyce, I.R., 1997. Seasonal patterns in soil moisture, vapour pressure deficit, tree canopy cover and predawn water potential in a northern Australian savanna. Australian Journal of Botany 45, 211-224.

Faulkes, J.J., 1998. Daly River Catchment: I An assessment of the physical and ecological condition of the Daly River and its major Tributaries. Northern Territory Dept. Lands, Planning and Environment. Technical Report TR99/10. Greacen, E.L, Walker, G.R., Cook, P.G., 1989. Procedure for filter paper method of measuring soil water suction. CSIRO Division of Soils. Divisional Report No. 108.

Hatton, T.J., Cook, P.G., O’Grady, A. Hutley, L., Reece, P., Farrow, R., Eamus, D., Pidsley, D., 1998. Hydrological investigation at Howard East, NT. 3. Paperbark swamp site: ecophysiology, soil physics, and groundwater chemistry. CSIRO Land and Water Technical Report 37/98.

Horton, J.L., Clark, J.L., 2000. Water table decline alters growth and survival of Salix gooddingii and Tamarix chinensis seedlings. Forest Ecology and Management $140,243-251$.

Horton, J.L., Kolb, T.E., Hart S.C., 2001. Responses of riparian trees to interannual variation in ground water depth in a semi arid river basin. Plant, Cell and Environment 24, 293-304. 
Jackson, P.A., Meinzer, F.C., Bustamante, M., Goldstein, G., Franco, A., Rundel, P.W., Caldas, L., Igler, E., Causin, F., 1999. Partitioning of soil water among tree species in a Brazilian cerrado ecosystem. Tree Physiology 19, 717-724.

Jackson, R.B., Cannadel, J., Ehleringer, J.R., Mooney, H.A., Sala, O.E., Schulze, E.D., 1996. A global analysis of root distributions for terrestrial biomes. Oecologia 108, 389-411.

Jolly, I.D., Walker, G.R., 1996. Is the field water use of Eucalyptus largiflorens F. Muell. affected by short-term flooding? Australian Journal of Ecology 21, 173183.

Mensforth, L.J., Thorburn, P.J., Tyermn, S.D., Walker, G.R., 1994. Sources of water used by riparian Eucalyptus camaldulensis overlying highly saline groundwater. Oecologia 100, 21-28.

O’Grady, A., Eamus, D., Cook, P., Lamontagne, S., Kelley, G., Hutley, L., 2003. Tree water use and sources of transpired water in riparian vegetation along the Daly River, Northern Territory. Department of Environment and Heritage, Canberra, Australia. http://www.deh.gov.au/water/rivers/nhrp/daly-river-2/pubs/dalyriver-2.pdf.

Patten, D.T., 1998. Riparian ecosystems of semi-arid North America: Diversity and human impacts. Wetlands, 18, 498-512.

Prior, L.D., Eamus, D., Duff, G.A., 1997. Seasonal and diurnal patterns of carbon assimilation, stomatal conductance and leaf water potential of Eucalyptus tetrodonta saplings in a wet-dry savanna in northern Australia. Australian Journal of Botany 45, 241-258.

Revesz, K., Woods, P.H., 1990. A method to extract soil water for stable isotope analysis. Journal of Hydrology 115, 397-406. 
Sophocleous, M., 1997. Managing water resources systems: why "safe yield" is not sustainable. Ground Water 35, 561.

Sophocleous, M., 2000. From safe yield to sustainable development of water resources - the Kansas experience. Journal of Hydrology 235, 27-43.

Stromberg, J.C., Tiller, R., Richter, B.D., 1996. Effects of groundwater decline on riparian vegetation of semi-arid regions: The San Pedro, Arizona. Ecological Applications 6, 221-235.

Thomas, D.S., Eamus, D., 2002. Seasonal patterns of xylem sap pH, xylem abscisic acid concentration, leaf water potential and stomatal conductance of six evergreen and deciduous Australian savanna tree species. Australian Journal of Botany 59, 229-236.

Thorburn, P.J., Mensforth, L.J., Walker, G.R., 1994. Reliance of creek-side river red gums on creek water. Australian Journal of Marine and Freshwater Research $45,1439-1443$.

Thorburn, P.J., Walker, G.R., Brunel J.-P., 1993. Extraction of water from Eucalyptus trees for analysis of deuterium and oxygen-18: laboratory and field techniques. Plant, Cell and Environment 16, 269-277.

Walker, G., Brunel, J.P., Dighton, J., Holland, K., Leaney, F., McEwan, K., Mensforth, L., Thorburn, P., Walker, C., 2001. The use of stable isotopes of water for determining sources of water for plant transpiration. CSIRO Land and Water, Technical Report 05/01.

Zencich, S.J., Froend, R.H., Turner, J.V., Gailitis, V., 2002. Influence of groundwater depth on the seasonal sources of water accessed by Banksia tree species on a shallow, sandy coastal aquifer. Oecologia 131, 8-19. 


\section{List of Figures}

Figure 1. Location of the Daly River Catchment, NT, and the two study sites. The direction of river flow is southeast to northwest. The Douglas/Daly site and the Douglas Daly Research Farm are within $1 \mathrm{~km}$ of one another.

Figure 2. Cross-section of the riparian zone for three transects sampled at Oolloo in 2000 - 20001. All distances and elevations relative to river level at the time of sampling (baseflow conditions). Deuterium values (\%o) of xylem sap, river, soil water and groundwater also shown. For trees, a range in deuterium values is given when three or more individuals of a given species were close together. When present, the height of the water table in test holes is shown with an inverted triangle.

Figure 3. Cross-section of the riparian zone for three transects sampled at the junction of the Douglas and Daly rivers in 2000 - 2001. Distances and elevations are relative to river level at the time of sampling (baseflow conditions). Deuterium values (\%o) of xylem sap, river water, soil water and groundwater are also shown. Deuterium value for groundwater estimated (see text). Douglas River deuterium value at 3 August 2001 estimated.

Figure 4. Soil matric potential and deuterium concentration as a function of depth for the levee $(a-b)$, terrace $(c-d)$, and riverbank (e-f) of Oolloo Transect 1, August 2001. 
The vertical dashed lines indicate a possible preferred range for soil water use (i.e., matric potential between 0 and $-1 \mathrm{MPa}$ ) and a probable upper limit for soil water use $(-3.5 \mathrm{MPa}$; see text) . Horizontally shaded boxes represent the range in xylem water deuterium for trees in the vicinity of the soil profiles. Closed circles represent matric potential with depth $(a, c)$ and deuterium with depth $(b, d)$.

Figure 5. Soil matric potential and deuterium concentration as a function of depth along the levee $(a-b)$, terrace $(c-d)$, and riverbank (e-f) of Douglas/Daly Transect 3, August 2001. On the terrace $(c-d)$, depth to groundwater and groundwater deuterium value estimated.

Figure 6. Deuterium values in xylem sap at the Douglas/Daly transects as a function of elevation above river level (i.e. an approximation of elevation above the water table at that site). The range in deuterium values expected for river/groundwater and soil water at this site is also provided. 


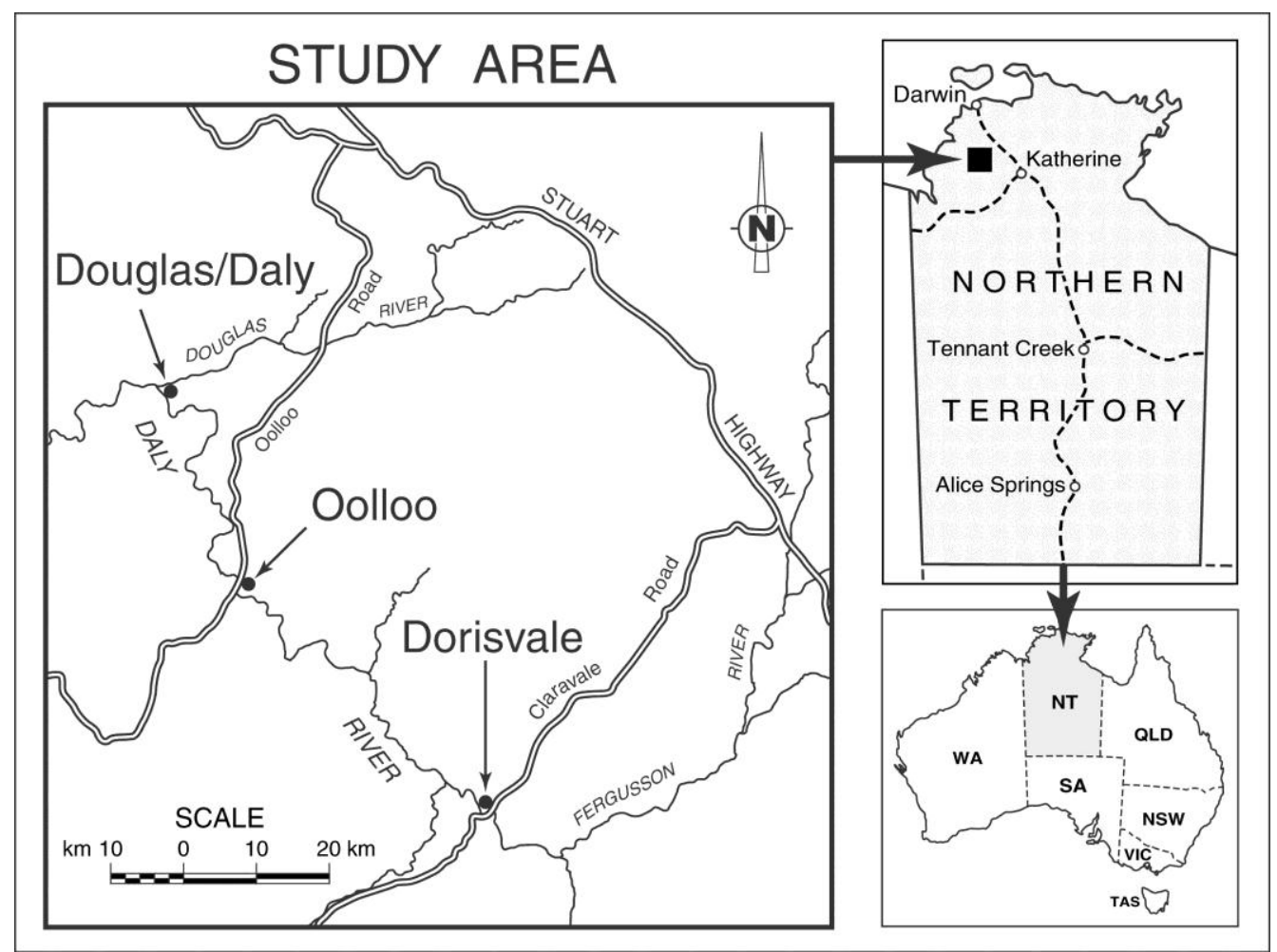

Fig. 1. 

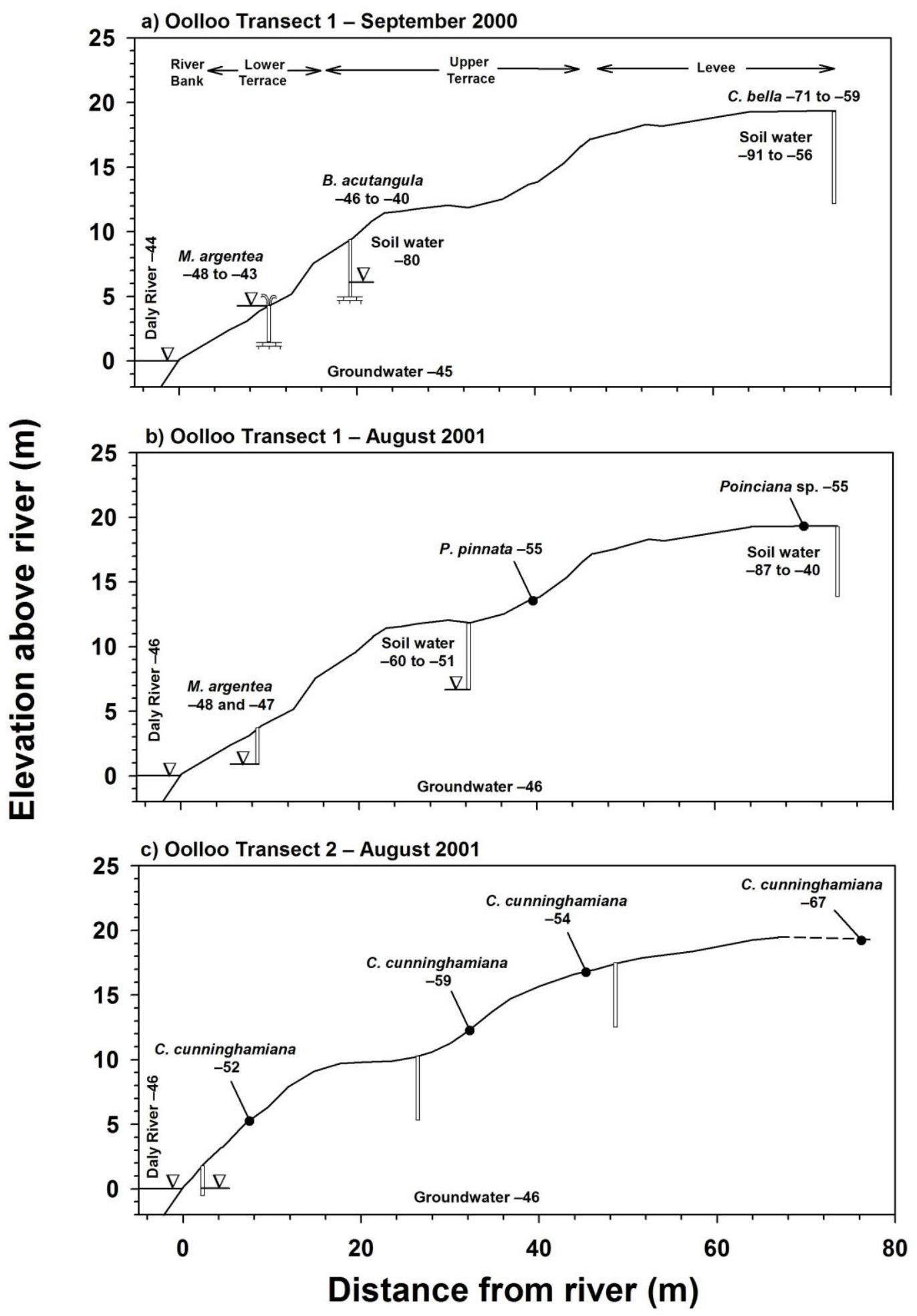

Fig. 2. 
a) Douglas/Daly Transect 1 - September 2000

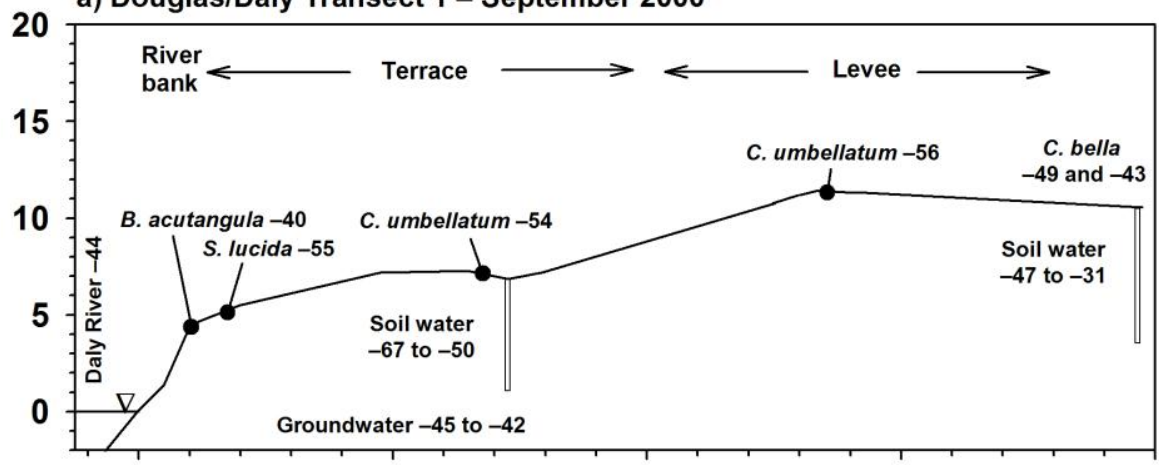

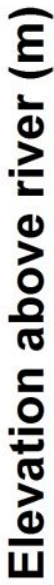

b) Douglas/Daly Transect 2 - September 2000

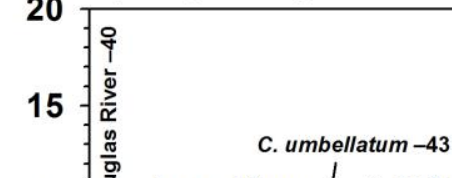

10 을 $\begin{gathered}\text { L. grandiflorum } \\ -40\end{gathered} \quad$ C. umbellatum -53

M. argentea
-42

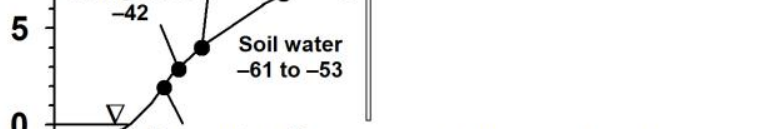

0

M. argentea -4

Groundwater -45 to -42

c) Douglas/Daly Transect 3 - August 2001

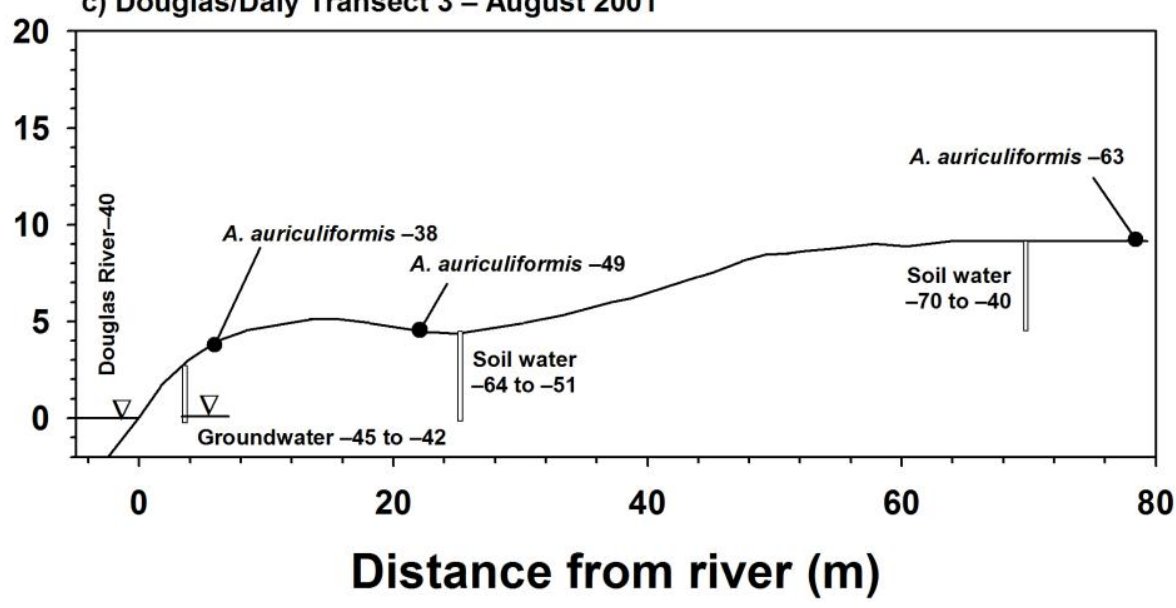

Fig. 3. 
Matric potential (-MPa)

$\delta^{2} \mathrm{H}(\%)$
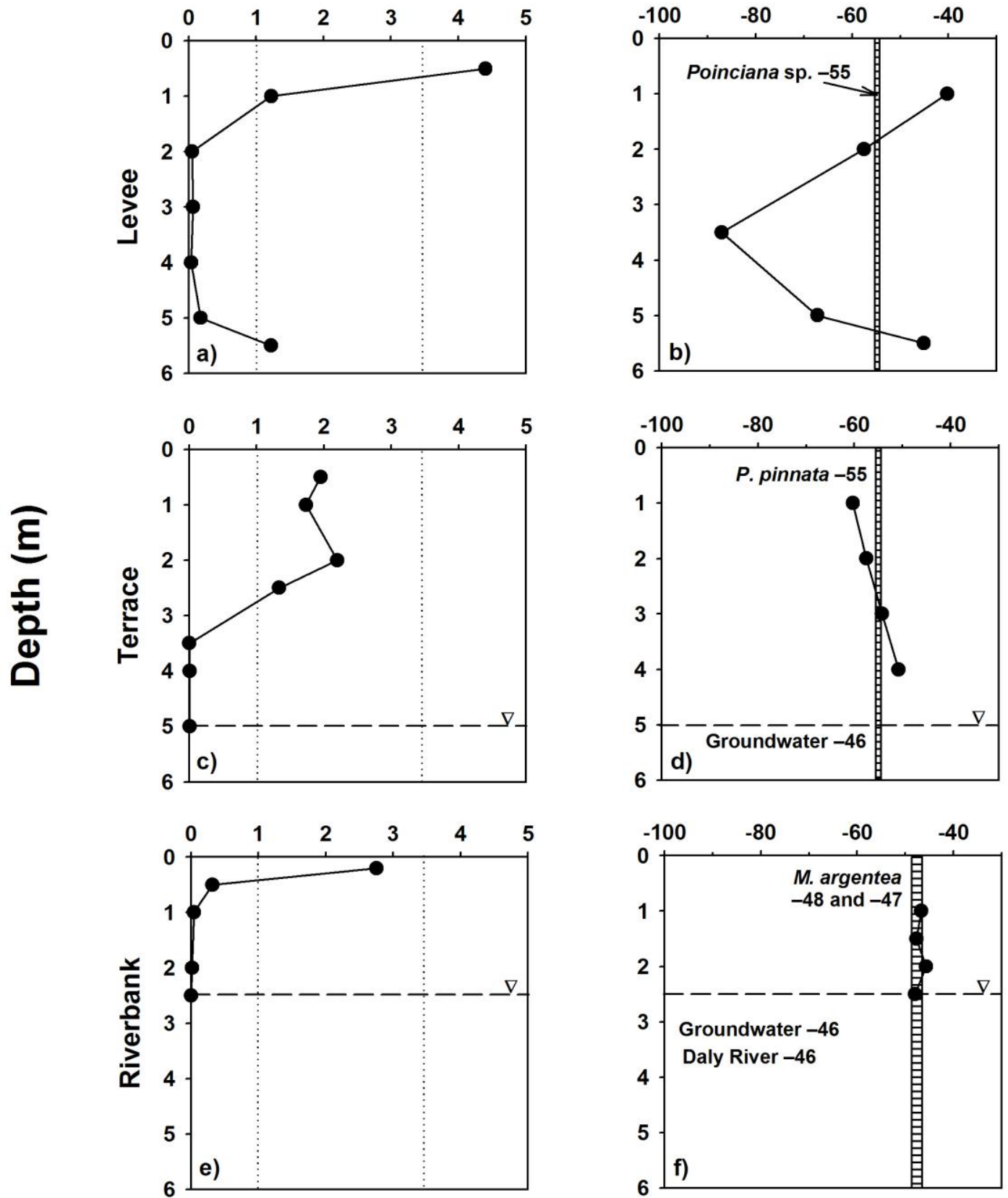

Fig. 4. 
Matric Potential (-MPa)
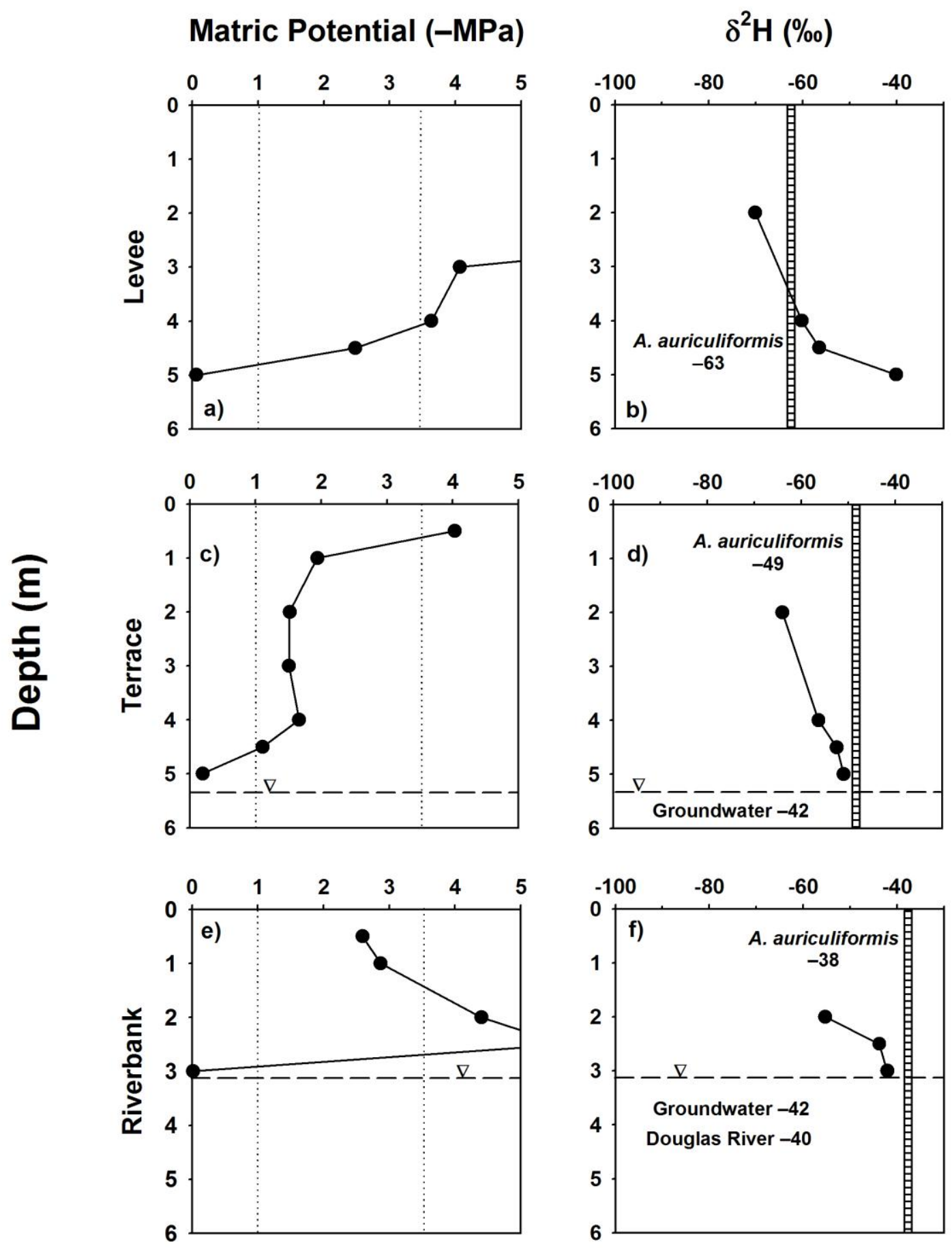

Fig. 5. 


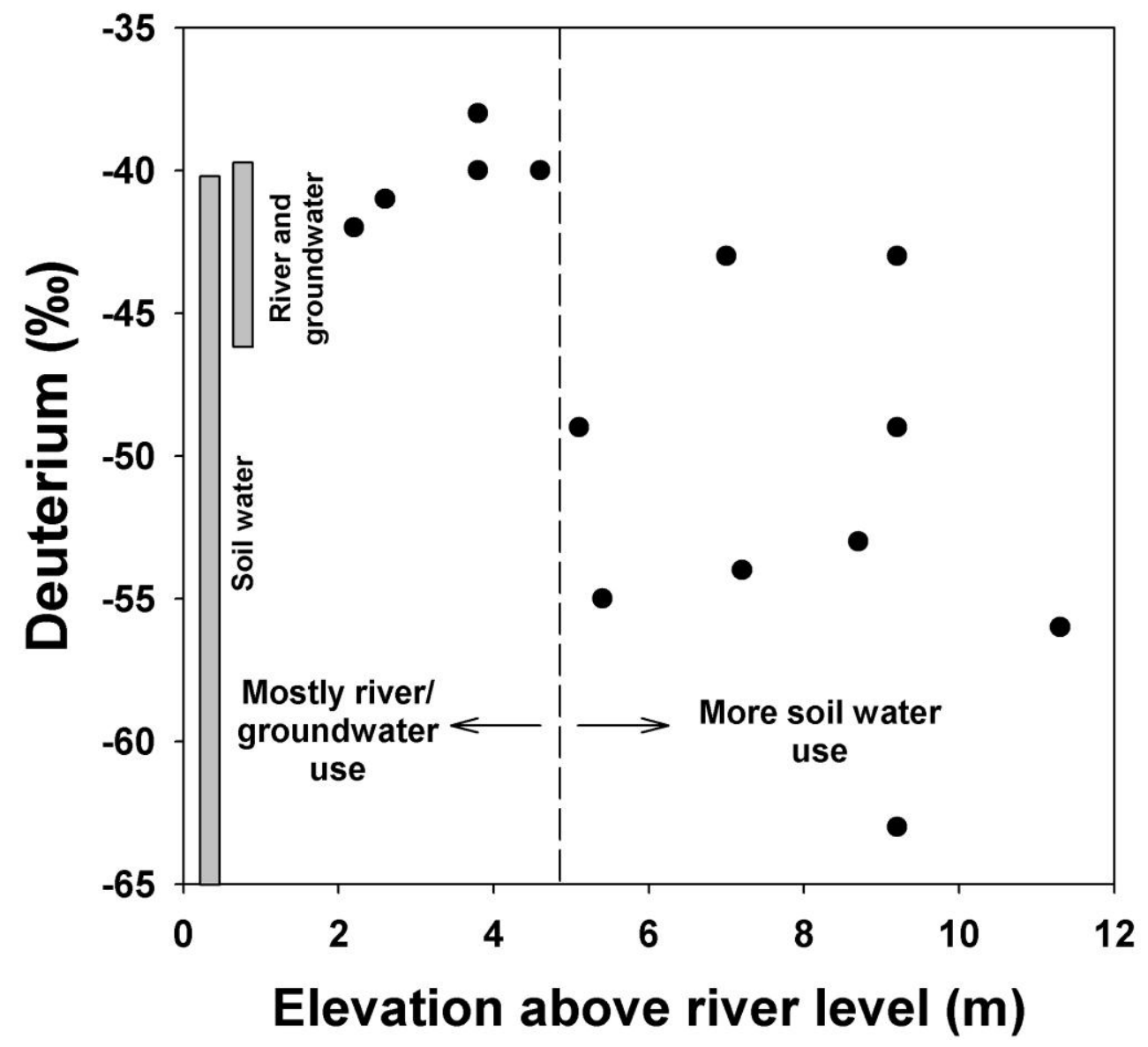

Fig. 6. 